Picture stories

\title{
Sturge-Weber syndrome with Klippel-Trenaunay syndrome and hypoplasia of internal carotid artery
}

\author{
${ }^{*}$ Neeraj Lata ${ }^{1}$, Anubha Sharma ${ }^{1}$, M S Pannu ${ }^{1}$, Narinder Singh ${ }^{1}$ \\ Sri Lanka Journal of Child Health, 2017; 46(4): 386-388 \\ DOI: http://dx.doi.org/10.4038/sljch.v46i4.8393
}

(Key words: Sturge Weber syndrome, Klippel-Trenaunay syndrome, hypoplasia of the internal carotid artery)

\section{Introduction}

Sturge Weber syndrome (SWS) is sporadic and is characterised by port wine stain, ipsilateral leptomeningeal angiomatosis, glaucoma, early onset seizures and neurodevelopmental delay ${ }^{1}$. Klippel-Trenaunay syndrome (KTS) is sporadic and is characterized by cutaneous and visceral haemangiomas, venous varicosities and soft tissue or bone hypertrophy ${ }^{2}$. The combination SWS and KTS has only been rarely reported ${ }^{3,4}$. Agenesis and hypoplasia of the internal carotid artery are also uncommon $^{5,6}$. We report a 13 year-old girl having features of both SWS and KTS along with hypoplasia of the internal carotid artery (ICA).

\section{Case report}

A 13 year old girl, born to non-consanguineous parents, presented with fever and vomiting for one day, followed by tonic clonic movements of right upper and lower limb with twitching of right side of face on the second day of admission for which she was treated with injection midazolam and phenytoin. She had a second episode of seizures on the $3^{\text {rd }}$ day for which she was adequately treated. She then developed weakness of the right side of the body for 3-4 days. Over the stay of 9 days in hospital her weakness improved. Her seizures were also controlled. There was a past history of seizures at 6 months of age for which anti-epileptics were given for 3 years and then stopped. There was no family history of similar complaints.

The blood pressure (BP) in all four limbs was more than the $99^{\text {th }}$ centile for her height and age. Port wine stain was present on both sides of the face and on the bridge of the nose (Figure 1).

${ }^{1}$ Government Medical College, Amritsar, Punjab, India

*Correspondence: vgotwal@yahoo.com

(Received on 28 July 2016: Accepted after revision on 23 September 2016)

The authors declare that there are no conflicts of interest

Personal funding was used for the project.

Open Access Article published under the Creative

Commons Attribution CC-BY cc) (i)
Microcephaly was present. Eye examination showed increased intraocular tension in left eye (glaucoma) and melanocytic pigmentation of both eyes (Figure 2). She had hypertrophy of the right upper and lower limbs (Figures 3 and 4). Right leg measured $24.5 \mathrm{~cm}$ and the left leg measured 21.5 $\mathrm{cm}$. Right thigh measured $37 \mathrm{~cm}$ and left thigh measured $34 \mathrm{~cm}$. Right and left mid arm circumference were $15.4 \mathrm{~cm}$ and $13 \mathrm{~cm}$ respectively. Right arm and right leg and thigh also had red coloured patches suggestive of angiomas. Neurological assessment showed decreased power (grade III Medical Research Council scale), exaggerated jerks, and increased muscle tone of the right upper limb and lower limb for 3-4 days of admission.

Magnetic resonance angiography of brain showed a reduced calibre of the left ICA, A1 segments of left anterior cerebral artery and left middle cerebral artery with paucity of vessels along the cortical and perisylvian segments of left ICA suggestive of congenital hypoplasia of left ICA (Figure 5). Ultrasound scan of the abdomen revealed serpiginous mass in left kidney suggestive of a vascular malformation.

Haemogram, serum electrolytes, cerebrospinal fluid examination and renal function tests were all normal.

\section{Discussion}

SWS is classified into 3 types according to the Roach Scale ${ }^{7}$. In type 1, facial and leptomeningeal angiomas are present and patient may have glaucoma. In type 2 facial angiomas are present without central nervous system (CNS) involvement and patient may have glaucoma. In Type 3, there are isolated leptomeningeal angiomas and usually no glaucoma. Our patient probably had type 2 SWS as she had facial haemangioma and glaucoma but no leptomeningeal angioma.

When there is complete failure of development of the ICA, the term agenesis is used and when ICA development has occurred but the artery is of a very small calibre the term hypoplasia is used ${ }^{8}$. The term aplasia is used when only vestiges of the ICA 
are present ${ }^{8}$. Many patients with agenesis or hypoplasia of the ICA are asymptomatic due to good collateral blood flow, and the anomaly may be detected only incidentally ${ }^{5,6}$. However, complications such as transient ischaemic attacks, infarcts, seizures, aneurysmal subarachnoid haemorrhage and parenchymal bleeds may occur $^{9,10}$. Our patient presented with seizures and hemiparesis which recovered over 2 weeks. This can be explained as the result of a transient ischaemic attack due to hypoplasia of ICA.

Capillary naevus, varicosities and tissue/bone hypertrophy of the affected limb are characteristic of $\mathrm{KTS}^{11}$. In KTS varicosities usually appear by 12 years of age $^{12}$. Microcephaly, macrocephaly, cerebral and spinal arteriovenous malformations and orbito-frontal varices are some CNS anomalies associated with $\mathrm{KTS}^{13}$. Our patient had hypertrophy of the right upper and lower limbs with associated ipsilateral cutaneous vascular malformations on upper and lower limbs and a serpiginous mass suggestive of haemangioma in the right kidney.

Several reports have been published where there is an overlap of KTS and SWS ${ }^{12}$. Our case represents an overlap syndrome between KTS and SWS in association with hypoplasia of ICA, which to the best of our knowledge has not been reported previously. In our case, the manifestations of SWS were on the left side of face but those of KTS were exclusively on the right side. There have been sporadic case reports of association of these two syndromes ${ }^{3,4}$. However, to the best of our knowledge, contralateral involvement of the two syndromes in the same patient has been documented in only one study ${ }^{13}$.

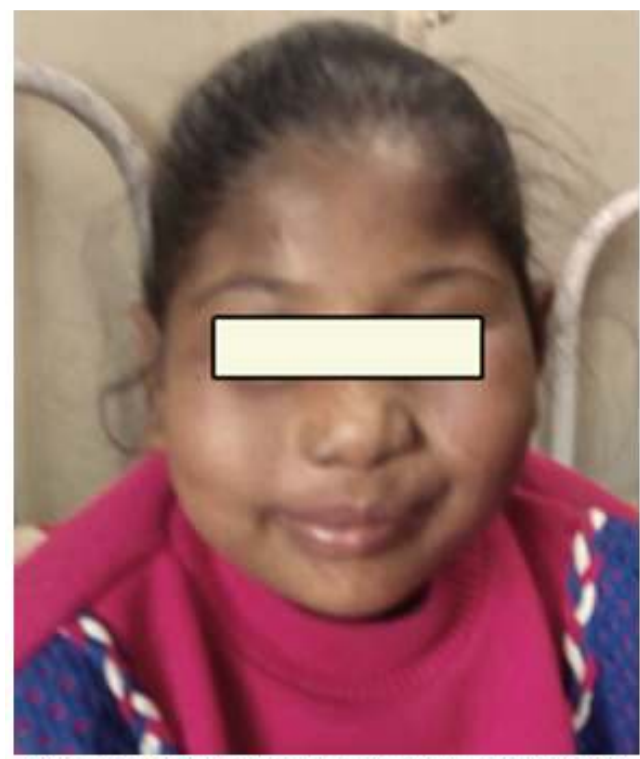

Figure 1: Port wine stain on both sides of face *Permission given by parents to publish photograph

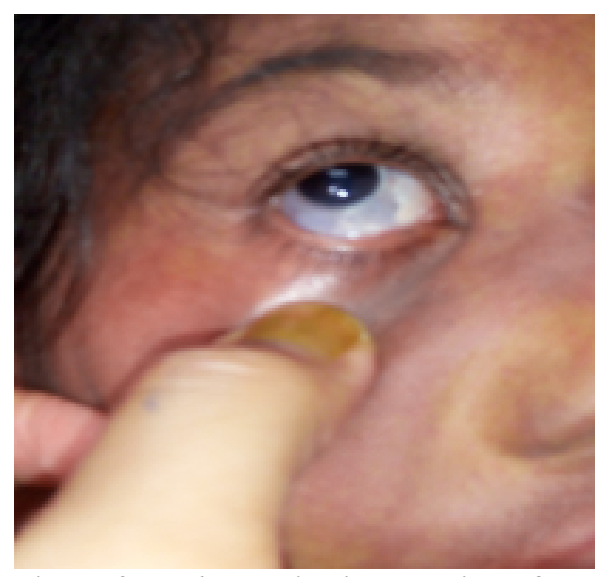

Figure 2: Melanocytic pigmentation of eye *Permission given by parents to publish photograph

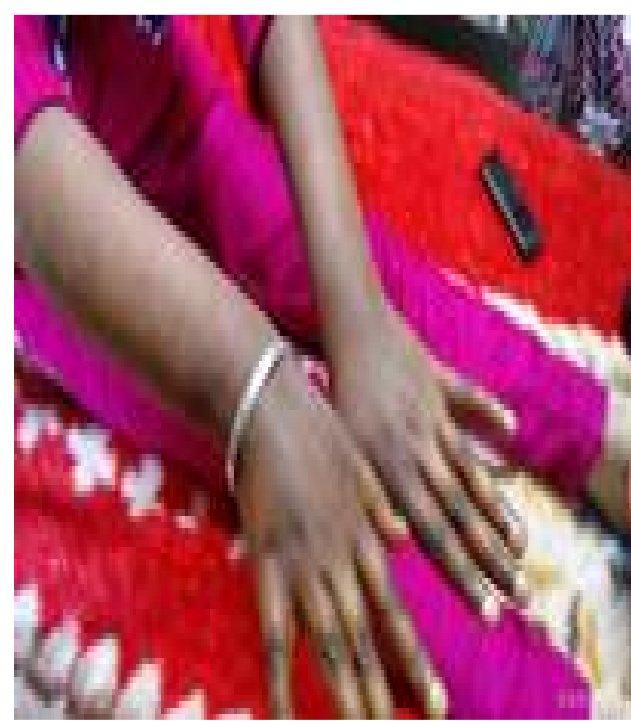

Figure 3: Hypertrophy of right upper limb

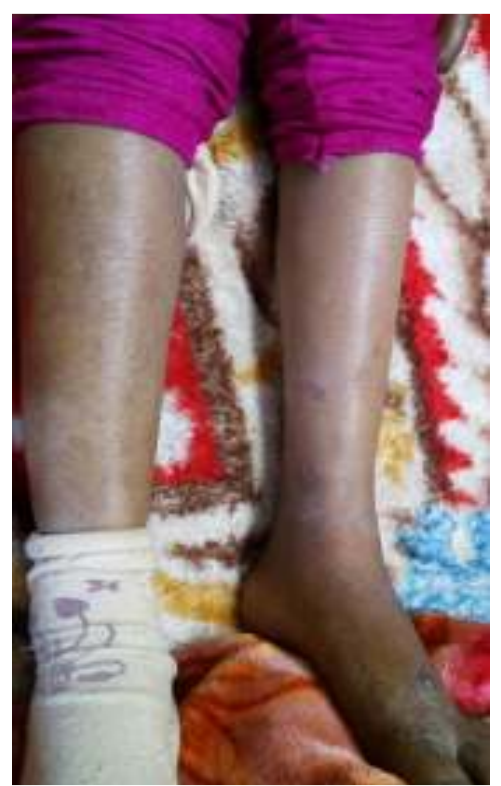

Figure 4: Hypertrophy of right lower limb 


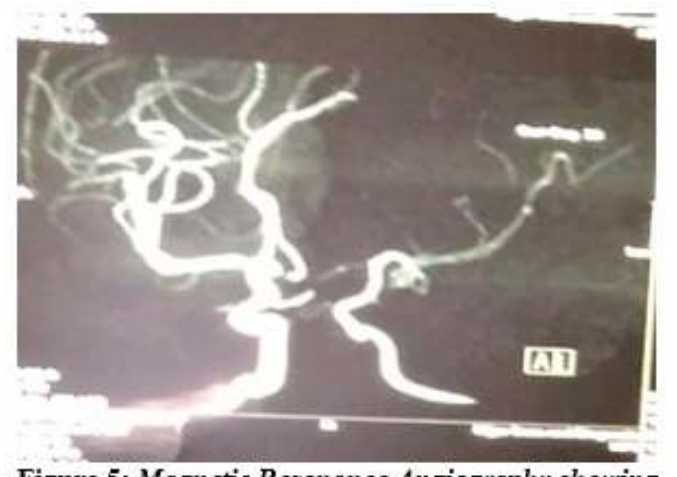

Figure 5: Magnetic Resonance Angiography showing internal carotid artery hypoplasia of left side

\section{References}

1. Sturge WA. A case of partial epilepsy apparently due to a lesion of one of the vasomotor centres of the brain. Transactions of the Clinical Society of London 1879; 12:162-7.

2. Lane A, Darmstadt GL. Distúrbios Vasculares. In: Behrman RE, Kliegman RM, Arvin AM, Nelson: Tratado de Pediatria. Rio de Janeiro: Editora Guanabara Koogan; 1997. p. 2128-32.

3. Deutsch J, Weissenbacher G, Widhalm K, Wolf G, Barsegar B. Combination of the syndrome of the Sturge-Weber and the syndrome of Klippel-Trenaunay. Klin Pediatr. 1976; 188:464-71.

PMid: 184345

4. Lee CW, Choi DY, Oh YG, Yoon HS, Kim JD. An infantile case of Sturge-Weber Syndrome in association with KlippelTrenaunay-Weber Syndrome and Phakomatosis Pigmentovascularis. Journal of Korean Medical Science 2005; 20:10824.

https://doi.org/10.3346/jkms.2005.20.6.1082 PMid: 16361829 PMCid: PMC2779316

5. Given CA, Huang-Hellinger F, Baker MD, Chepuri NB, Morris PP. Congenital absence of the internal carotid artery: Case reports and review of the collateral circulation. AJNR American Journal of Neuroradiology 2001; 22:1953-9.

PMid: 11733331

6. Lee JH, Oh CW, Lee SH, Han DH. Aplasia of the internal carotid artery. Acta Neurochir (Wien) 2003; 145:117-25. https://doi.org/10.1007/s00701-002-1046-y PMid: 12601459
7. Roach ES. Neurocutaneous syndromes. Pediatric Clinics of North America 1992; 39(4):591-620.

https://doi.org/10.1016/S00313955(16)3836 7-5

8. Ito $\mathrm{S}$, Miyazaki $\mathrm{H}$, Iino $\mathrm{N}$, Shiokawa $\mathrm{Y}$, Saito I. Unilateral agenesis and hypoplasia of the internal carotid artery: A report of three cases. Neuroradiology 2005; 47: 3115 .

https://doi.org/10.1007/s00234-003-1090-1 PMid: 15868172

9. Erdem Y, Yilmaz A, Ergun E, Kofiar U, Karatay M, Bayar MA. Bilateral internal carotid artery hypoplasia and multiple posterior circulation aneurysms. Importance of 3DCTA for the diagnosis. Turkish Neurosurgery. 2009; 19:168-71.

PMid: 19431129

10. Chen CJ, Chen ST, Hsieh FY, Wang LJ, Wong YC. Hypoplasia of the internal carotid artery with intercavernous anastomosis. Neuroradiology 1998; 40: 252-4 https://doi.org/10.1007/s002340050578 PMid: 9592798

11. Verhelst H, Van Coster R. Neuroradiologic findings in a young patient characteristic of Sturge-Weber syndrome and KlippelTrenaunay syndrome. Journal of Child Neurology 2005; 20: 911-3. https://doi.org/10.1177/08830738050200110 901

PMid: 16417862

12. Berry SA, Peterson C, Mike W. KlippelTrenaunay syndrome. American Journal of Medical Genetics 1998; 79:319-26.

https://doi.org/10.1002/(SICI)10968628(199 81002)79:4<319::AIDAJMG15>3.0.CO;2-U

13. Williams DW III, Elster AD. Cranial CT and MR in the Klippel-Trenaunay-Weber syndrome. American Journal of Neuroradiology 1992; 13: 291-4.

14. Purkait R, Samanta T, Chatterjee M. Overlap of Sturge-Weber syndrome and KlippelTrenaunay syndrome. Indian Journal of Dermatology 2011; 56(6): 755-7. https://doi.org/10.4103/0019-5154.91848 PMid: 22345790 PMCid: PMC3276916 